\title{
Bankruptcy Risk and Financial Performance of Companies Listed on the Stock Exchange of Thailand
}

\author{
Thitima Chaiyakul ${ }^{1}$ \\ ${ }^{1}$ Management Sciences Faculty, Kasetsart University, Chonburi, Thailand \\ Correspondence: Thitima Chaiyakul, Management Sciences Faculty, Kasetsart University, Chonburi, Thailand. Tel: \\ 66-38-352-381.
}

Received: January 25, 2021

Accepted: March 3, 2021

Online Published: March 31, 2021

doi:10.5430/ijfr.v12n4p78

URL: https://doi.org/10.5430/ijfr.v12n4p78

\begin{abstract}
Financial performance is an important issue for entrepreneurs and investors. So far the number of studies on the effect of bankruptcy risk on financial performance of firms is small. Hence, this research investigates the impact of bankruptcy risk on financial performance of companies listed on the Stock Exchange of Thailand and the relevant data cover the period between 2015 and 2019. Excluded are companies operating in the finance industry. The data are analyzed by multiple regression analysis. Altman's Z-score (1968) is used as a proxy for bankruptcy risk while ROA, ROE, and Tobin's Q serve as proxies for financial performance. The control variables in this study are liquidity, capital structure, firm size, and inflation rate. Results reveal that Altman's Z-score and firm size statistically and positively affect financial performance proxied by both accounting-based-measures, i.e. ROA and ROE; and market-based measures, i.e. Tobin's Q. These results confirm that companies listed on Thailand's Stock Exchange have low bankruptcy risk and large size is financially performed well.
\end{abstract}

Keywords: bankruptcy risk, financial performance, stock exchange of Thailand

\section{Introduction}

Studies on firms' financial performance have been increasingly published and received widespread attention from corporate finance researchers worldwide. Financial performance represents an organization's operational abilities or capacity to use resources to generate profits for entrepreneurs and shareholders. There are a range of factors explaining the changes in financial performance that can benefit all relevant stakeholders. Firms are now armed with guidelines and regulations on business strategy, practices, responsibilities, etc., that aims to improve their performance and create a competitive advantage in the marketplace.

Changes in financial performance not only affect a company, but it may affect the industry in which it operates, other stakeholders in the supply chain, namely suppliers, shareholders, creditors, distributors and customers. If one company can generate good financial turnover, it will result in benefits for those involved in the supply chain and ultimately the distribution of revenue to other businesses, as well as helping the country's economy expand. When the economic conditions in each country expand this in turn feeds into the global economy and its functioning. Conversely, poor global economic conditions may also trigger crises in the financial performance of domestic businesses, such as the South East Asian Financial Crisis in 1997-1998, Global Financial Crisis of 2007-2009, and the COVID-19 outbreak in 2020. These have all to a great extent damaged companies and entire economies, so a company's ability to explain changes in financial performance may also help it to recover and function in new ways.

The financial performance of a business is information used by investors to make their investment decisions, and in the context of good financial performance, and then the investor will have confidence and invest in it. In contrast, if a company is performing poorly in financial terms, the company will not satisfy customers, is at great risk of losing market share, and may in fact collapse. Especially, during an economic crisis, the company may experience great difficulties to maintain its market value and financial viability, triggering a loss of confidence in investors who may withdraw or sell their shareholdings.

Based on a review of published research on the factors affecting financial performance, there are: firstly external factors, namely inflation, interest rate, exchange rate and gross domestic product, etc.; and secondly, internal factors, these being firm size, growth opportunities, and capital structure. However, the number of papers on the impact of 
bankruptcy risk on financial performance is still small and the effect of bankruptcy risk on financial performance has led to inconclusive results. Analyses have been done on the impact of default risk and financial performance in Asian markets such as Singapore (Foo, 2015; Liang \& Pathak, 2018b), Hong Kong (Foo, 2015), South Korea (Foo \& Pathak, 2016), Taiwan (Foo \& Pathak, 2016), People's Republic of China (Liang \& Pathak, 2018a), Pakistan (Mahmood, Rizwan, \& Rashid, 2018) and Malaysia (Ho \& Raff, 2019). So far there is no research published on the impact of the risk of default on financial performance of companies listed on the Stock Exchange of Thailand. Additionally, among a small number of previous studies, there are no studies that employed cross-sectional analyses for bankruptcy risk as measured by Altman's Z-score (1968) and alternative measures of financial performance. To contribute the knowledge according to this research area, this study examines the impact of bankruptcy risk measured by Altman's (1968) Z-score augmented with four control variables, namely: liquidity, debt-to-equity ratio, size of firm, and inflation on the financial performance measured by three different measurements which are ROA, ROE, and Tobin's Q.

A study on impact of bankruptcy risk on financial performance of companies listed on the Stock Exchange of Thailand can help agencies or other institutions evaluate the financial policy of the business and to plan and make financial strategies to improve financial performance. This research is relevant for investors who want to invest in companies listed on the Stock Exchange and especially consider those factors that can have implications for their investment decisions, in the context of knowledge about the risk of defaulting for such companies. This study is organized as follows: Section 2 reviews the existing literature. Section 3 describes the research design, data and methodology. Section 4 discusses the empirical evidence and section 5 concludes the study with a summary of the main themes covered here.

\section{Literature Review}

\subsection{Bankruptcy Risk Measurement}

According to the research done on bankruptcy risk, certain models have been devised to estimate the financial stability of the business or to predict the bankruptcy risk of firms. In other word, if a company has a low probability of defaulting on its debts, this means it has a high level of financial stability. Beaver (1966) developed a model to forecast the likelihood of default of companies in the U.S. using financial ratios, and the results show that these financial ratios could predict statistically significant bankruptcy opportunities. After Beaver (1966) research, subsequent studies developed a default forecast model. Again in the U.S., Altman (1968) used data from companies to create a model based on financial and non-financial statements that explain short-term liquidity, profitability, leverage, solvency and business activity ratios. This model is more commonly known as Altman (1968) Z-score. Altman (1968) research led to more bankruptcy risk prediction models being done in the United States and elsewhere, such as: Ohlson (1980), Zmijewski (1984), Altman, Eom, and Kim. (1995), Nam and Jinn (2000), Charitou, Neophytou, and Charalambous. (2004), and Chen, Marshall, Zhang, and Ganesh (2006). Although many bankruptcy risk prediction models have been formulated, Altman (1968) Z-score is one of popular and long-lasting ones applied to the world's emerging market economies. For instance, Mardaconsita and Soelton (2019) used Altman (1968) Z-score to measure the potential of financial distress in plantation-based industries in Indonesia. Panrod (2017) used Altman (1968) Z-score to investigate financial distress in property development companies listed on the Stock Exchange of Thailand for the period 2012-2015.

\subsection{Financial Performance Measurement}

Financial performance indicators can be divided into two groups. The first comprises accounting-based measures, which are indicators based on collected data from accounting statements of firms, such as return on equity (ROE), return on assets (ROA), return on sale (ROS), net income, etc. The second consists of market-based measures derived from equity market data, for instance return on common stock, market capitalization, and Tobin's Q model. Accounting-based indicators are calculated based on companies' accounting information where comparisons can be made; however, accounting information can also refer to non-current information. Meanwhile, the market-based indicators derived from the stock market data reflect a company's current changing situation better than the information generated by accounting statements. Nevertheless, financial performance of firms measured from market information may be influenced by external factors like economic, political, social, and technological factors. According to a review of related research papers, popular indicators used to represent the financial performance of companies are return on equity (ROE), return on assets (ROA) and Tobin's Q (Garcia-Castro, Ariño,\& Canela, 2010; Rodgers, Choy, \& Guiral, 2013; Foo, 2015; Foo \& Pathak, 2016; Liang \& Pathak, 2018a; Liang \& Pathak, 2018b; Hillary, Nyang'au, \& Ngacho, 2018; Ho and Mohd-Raff, 2018). 


\subsection{Bankruptcy Risk and Financial Performance}

Among a number of studies on the subject of bankruptcy risk and financial performance, are those which investigated those factors indicating financial performance. One includes bankruptcy risk factor as a proxy for financial health measurement of a company. A company in the position of low bankruptcy risk is one experiencing good financial health. Based on the existing published research, studies on the impact of bankruptcy risk on financial performance is limited, and the results are conflicting. Most outcomes show that the financial health of a business has a statistically and positively significant impact on its financial performance. However, some research has found that financial health has a statistically insignificant impact on financial performance.

Foo (2015) studied the relationship between the financial health of the business and the financial performance of manufacturing companies listed on the Singapore and Hong Kong stock exchanges between 2000 and 2013. The study measured the financial health using Altman (1968) Z-score and estimated company performance with ROE. The results showed that the financial health was positively correlated with statistically significant financial performance in both stock exchanges. As well, it found that companies in Hong Kong and Singapore had moderate to high financial health. Foo and Pathak (2016) studied the relationship between the financial health and performance of manufacturing companies listed on the South Korean and Taiwan stock exchanges between 2000 and 2013. Similar to Foo (2015), they measured financial health or the risk of default using Altman's Z-score and calculated the financial performance by ROE. Their results demonstrated that financial health was positively correlated and statistically significant to performance in both the Singapore and Hong Kong stock markets. Similarly, Liang and Pathak (2018a) examined the relationship between financial health and performance of manufacturing companies listed on China's Stock Exchange between 2013 and 2017. Liang and Pathak (2018b) studied the relationship between financial health and performance for manufacturing companies listed on the Singapore stock exchange during 2013-2017. Both Liang and Pathak (2018a) and Liang and Pathak (2018b) found that financial health measured by Altman's Z-score is statistically positively correlated with financial performance as measured by ROE.

Most previous research, namely Foo (2015), Foo and Pathak (2016), Liang and Pathak (2018a), and Liang and Pathak (2018b) found positive relationships between financial health and performance of firms operating in the stock markets of Singapore, Hong Kong, South Korea, and Taiwan. Interestingly, these research studies measured the financial health using the bankruptcy risk prediction model, Altman's Z-score, and ROE. Businesses experiencing good financial health or low bankruptcy risk will perform well financially. A simple regression analysis is used to determine the relationship between financial health and firm performance.

On the other hand, some studies have found a statistically insignificant relationship between bankruptcy risk and financial performance. Ho and Mohd-Raff (2019) examined external and internal determinants of how well Shariah and non-Shariah-compliant firms performed on the Malaysia Stock Exchange during 1999-2015. ROA and ROE served as measurements of firm performance and financial health was measured by the ratio of debt to total assets. Their findings showed that financial health insignificantly affects the performance of non-Shariah-compliant firms but it is significant for Shariah-compliant businesses. Elsewhere, Hillary et al. (2018) studied the effects of financial distress on financial performance of manufacturing companies listed on the Nairobi Stock Exchange, Kenya, from 2011 to 2015. Employing the linear regression analysis, their results revealed that financial distress does not affect the financial performance of firms in Kenya at 0.05 statistical significance. ROA and ROE are the measures of financial performance and Altman's Z-score is a measure of financial distress of firms. The liquidity ratio and debt-to-equity ratio are used as control variables.

Mahmood et al. (2018) examined the relationship between financial distress, financial flexibility and firm performance for companies listed on the Pakistan Stock Exchange during 1992 to 2014. Altman's Z-score is used to measure financial distress or bankruptcy risk and ROA measures financial performance in their study. Other independent variables, namely market-to-book value ratio, firm size, tangible asset ratio, profitability ratio, cash holding ratio, business life, dividend policy, inflation rate, and financial flexibility, as control variables, are included in the analysis of the relationship between Z-score and ROA. The results revealed that financial distress does not affect financial performance of firms in Pakistan with a statistical significance level at 0.05 . However, they found that market-to-book value ratio, cash holding ratio, dividend policy, and financial flexibility can explain changes in financial performance with a statistical significance level at 0.05 . Concerning the small amount of published research on the relationship between bankruptcy risk and financial performance, data on Thailand is rare. Despite there being several published studies on financial distress and financial performance in Thailand, only Panrod (2017) examined the level bankruptcy risk in that country's companies using Altman's Z-score. However, Panrod (2017) did not evaluate the relationship between bankruptcy risk and financial performance. 


\subsection{Other Determinants of Financial Performance}

From the review the relevant research, there are many studies on the determinants of financial performance. Apart from bankruptcy risk, many factors are examined for their effect on financial performance including liquidity, leverage ratio, firm's size, and inflation. The influence of liquidity on financial performance has received some attention in prior research. Most studies found that liquidity has a positive impact on financial performance and this implied that firms having the capacity to repay short-term debts employ effective short-term credit management and credit collection strategies. These businesses can generate profits and perform well (Muhammad, Jibril, Wambai, Ibrahim, \& Ahmad, 2015; Usama, 2012; Anser \& Malik, 2013; Bibi \& Amjad, 2017). However, evidence a negative relationship between liquidity and financial performance has been detected in previous research. Where firms have too much liquidity, this means they are unable to manage short-term assets effectively. The presence of large amounts of short-term assets can be caused by large inventories, high levels of short-term debt, lack of cash efficiency, which can result in higher operating costs and result in business profitability declining (Eljelly, 2004; Raheman \& Nasr, 2007).

Prior research has found both positive and negative effects of leverage ratio or debt-to-equity ratio on financial performance. The positive impact of leverage ratio originates from the proportion of external financing being higher than internal financing. This results in tax benefits from interest payments on loans. Additionally, costs of external financing probably are less than the costs of issuing equity. Consequently, a company increases its profitability and enjoys higher turnover (Ramli, Latan, \& Solovida, 2019; Rub, 2012). A negative impact of debt-to-equity ratio on financial performance occurs when the company borrows funds at a high interest rate, resulting in financing costs that are more than the company's profits (Rouf, 2015; Pratheepkanth, 2011).

In previous studies, firm size is another popular factor that been tested for its effect on financial performance. Most results show that a firm's size is positively and statistically related to financial performance. Large firms can purchase large volumes of materials and keep them as part of the inventory over the long-term, and they will receive quantity discounts from suppliers. Moreover, larger companies are likely to receive higher credit limits and longer credit periods than smaller companies, which result in lower business costs and higher profits, which means better turnover. Consequently, the size of a firm has a significant positive impact on financial performance (Eljelly, 2004; Bibi \& Amjad, 2017; Rouf, 2015). Inflation is another factor that has emerged as wielding a significant impact on financial performance. Inflation indicates the rate of price growth of goods and services in the country and reflects the economic conditions of the country over time. Therefore, inflation would affect both the costs of materials and sales, and subsequently a company's profit. Interestingly, research has found both positive and negative correlation to business performance (Oleka, Sabina, \& Ebue, 2015; Ali \& Ibrahim, 2018).

To the best of the author's knowledge, studies on the relationship between bankruptcy risk and financial performance are few, especially in Thailand and the evidence is inconclusive. To fill the gaps in our knowledge, this study examines the impact of bankruptcy risk on financial performance of companies listed on the Stock Exchange of Thailand. The conceptual framework devised to explain it is shown in Figure 1. The bankruptcy risk measured by Altman's (1968) Z-score tests the impact augmented with four control variables, namely: liquidity, debt-to-equity ratio, size of firm, and inflation on the financial performance measured by three different measurements. These are ROA, ROE, and Tobin's Q.

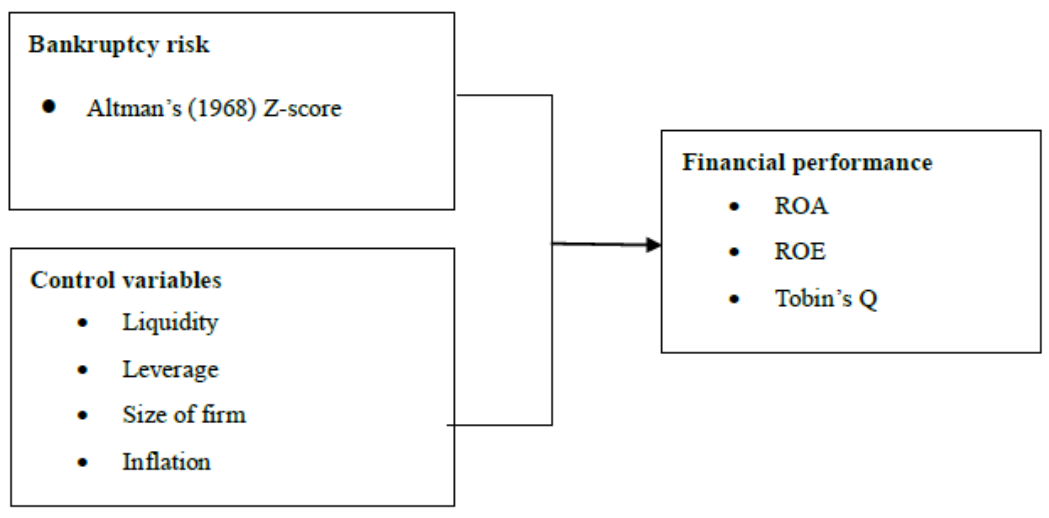

Figure 1. A conceptual framework 


\section{Methodology}

To study the impact of bankruptcy risk on financial performance of companies listed Thailand's Stock Exchange, data of companies listed covers the period between January, 2015 and December, 2019 and collected from Datastream. Companies operating in the finance industry are excluded because they have different accounting practices. Next, the multiple-regression models are employed in this study and presented as follows:

$$
\begin{aligned}
& \mathrm{ROA}_{\text {it }}=\mathrm{a}_{0}+\mathrm{b}_{1} \mathrm{Z}_{\text {it }}+\mathrm{b}_{1} \mathrm{LIQ}_{\mathrm{it}}+\mathrm{b}_{2} \mathrm{CS}_{\text {it }}+\mathrm{b}_{4} \mathrm{SIZE}_{\text {it }}+\mathrm{b}_{4} \mathrm{INF}_{\text {it }} \\
& \mathrm{ROE}_{\text {it }}=\mathrm{a}_{0}+\mathrm{b}_{1} \mathrm{Z}_{\mathrm{it}}+\mathrm{b}_{1} \mathrm{LIQ}_{\text {it }}+\mathrm{b}_{2} \mathrm{CS}_{\text {it }}+\mathrm{b}_{4} \mathrm{SIZE}_{\text {it }}+\mathrm{b}_{4} \mathrm{INF}_{\text {it }} \\
& \text { Tobins } Q_{i t}=a_{0}+b_{1} Z_{i t}+b_{1} L Q_{i t}+b_{2} C S_{i t}+b_{2} C_{i t}+b_{4} S_{I Z E}{ }_{i t}+b_{4} I_{N F}
\end{aligned}
$$

Financial performance is measured by three different indicators: return on assets $\left(\mathrm{ROA}_{\mathrm{it}}\right)$ which is the ratio of net profits to total assets of company $i$ at year $t$; return on equity $\left(\mathrm{ROE}_{\mathrm{it}}\right)$ which is the ratio of net profits to equity of company $\mathrm{i}$ at year $\mathrm{t}$; and Tobin's $\mathrm{Q}$ (Tobins $\mathrm{Q}_{\mathrm{it}}$ ) which is market value plus preferred stock plus total debts to total assets of company i at year $t$ (Chung and Pruitt, 1994).

Bankruptcy risk in this study is measured by Altman's (1968) Z-score which is calculated as follows:

$$
\mathrm{Z}=1.2 \mathrm{X}_{1}+1.4 \mathrm{X}_{2}+3.3 \mathrm{X}_{3}+0.6 \mathrm{X}_{4}+0.999 \mathrm{X}_{5}
$$

Where, $X_{1}$ is the ratio of working capital to total assets, $X_{2}$ is the retained earnings to total assets, $X_{3}$ is the ratio of earnings before interest and tax to total assets, $X_{4}$ is the market value of equity to total liabilities, and $X_{5}$ is sales to total assets. Working capital is calculated by taking current assets minus current liabilities. The market value is calculated from the share price multiplied by the number of shares issued. Altman's Z-score can divide the financial health of the business into three types: if the Z-score is more than 2.675 , this indicates the company has high financial stability (safe zone); if Z- score is between 1.81 and 2.675 , it suggests that the company is more likely to experience financial difficulties (gray zone); if Z-score is less than 1.81, it means the company is at high risk of bankruptcy (weak zones). Additionally, there are 4 control variables in equations (1), (2), and (3) where: LIQ $Q_{i t}$ is the liquidity ratio calculated by the current assets to current liabilities of company $\mathrm{i}$ at year t.; $\mathrm{CS}_{\text {it }}$ is the capital structure measured by total liabilities to equity of company $i$ at year $t$; SIZE $_{i t}$ is the size of firm calculated by the natural logarithm of the market value of the equity of firm $i$ at year $t$; and $\mathrm{INF}_{\mathrm{t}}$ is inflation rate or the change in the consumer price index at year $t$.

\section{Results and Discussion}

This section discusses the results for the impact of risk of default on the performance of companies listed on the Stock Exchange of Thailand. Table 1 presents the descriptive statistics of the variables used in this study. To measure the financial performance of these companies between 2015 and 2019, three different measurements are employed: Return on assets (ROA), Return on equity (ROE) and Tobin's Q. It found that the average ROA of Thai listed companies is $4.502 \%$. This reveals that, on average, companies could profit from total assets and the results also show that the average ROE is 8.07. Thus on average, listed companies were able to make profits for their shareholders. However, the average Tobin's Q of listed companies is 0.395 . It indicates that generally the Thai listed companies were not able to use their assets efficiently because Tobin's $\mathrm{Q}$ was less than 1 .

Table 1. Descriptive statistics

\begin{tabular}{lllll}
\hline Variables & Mean & StDev & Minimum & Maximum \\
\hline ROA $(\%)$ & 4.502 & 8.753 & -81.697 & 69.661 \\
\hline ROE $(\%)$ & 8.076 & 23.162 & -342.550 & 119.040 \\
\hline TobinQ & 0.395 & 0.221 & 0.001 & 1.483 \\
\hline Z & 0.826 & 0.697 & -0.007 & 8.353 \\
\hline Liq ratio & 3.029 & 11.896 & 0.012 & 388.680 \\
\hline D/E & 4.320 & 127.950 & -11.650 & 6265.870 \\
\hline $\ln$ TA & 15.595 & 1.509 & 10.021 & 21.568 \\
\hline Inf $(\%)$ & 0.584 & 0.930 & -0.899 & 1.898 \\
\hline
\end{tabular}


In Table 1, the average values of other variables employed are presented. The average Altman's Z-score was 0.826. According to Altman (1968), it explains that between 2015 and 2019, the companies listed on the Stock Exchange of Thailand are highly likely to experience financial problems. However, when considering the ability to repay short-term debts or liquidity, as measured by liquidity ratios, the results show that the average liquidity ratio of companies is 3.029. So overall, the companies can convert short-term assets into cash and repay short-term liabilities. Furthermore, the results also show that the average of debt-to-equity ratio is 4.32 . Therefore, the sources of funds of are mainly derived from borrowing. Added to this the results found that the companies had a natural logarithm of total asset at $15.59 \%$ and Thailand had an average inflation rate of $0.584 \%$ during 2015 to 2019 .

To test the impact of bankruptcy risk on financial performance of companies listed on Thailand's stock exchange, this research examined the preliminary agreements on the use of multiple regression analysis statistics, namely Pearson's Correlation Coefficient and the Variance Inflation Factor (VIF). These help to test conditions in which independent variables should not have a relationship within tested variables (known as multicollinearity). Pearson's Correlation Coefficient values are presented in Table 2 and those values are no more than 0.382. These would explain that the independent variables are correlated with each low level. Therefore, there are no multicollinearity issues among the independent variables (Hinkle, 1998). Meanwhile the results of the variance inflation factor (VIF) test shown in Table 3 revealed that the variance expansion factor values are less than 10 in all variables. It means that the independent variables are independent of each other. It does not cause problems with the internal relationship (multicollinearity). When considering the Durbin-Watson statistics tested for autocorrelation in Table 3, the results present that Durbin-Watson statistical value in three multiple regression models are between 1.99 and 2.04. Consequently, each independent variable is independent of the other variables.

Table 2. Pearson's correlation coefficient

\begin{tabular}{|c|c|c|c|c|c|c|c|c|}
\hline & ROA & ROE & Tobin's Q & $\mathrm{Z}$ & Liq ratio & $\mathrm{D} / \mathrm{E}$ & $\ln \mathrm{TA}$ & Inf \\
\hline ROA & 1.000 & & & & & & & \\
\hline \multirow[t]{2}{*}{ ROE } & $0.194 * * *$ & 1.000 & & & & & & \\
\hline & $(0.000)$ & & & & & & & \\
\hline \multirow[t]{2}{*}{ Tobin's Q } & $-0.251 * * *$ & -0.034 & 1.000 & & & & & \\
\hline & $(0.000)$ & $(0.115)$ & & & & & & \\
\hline \multirow[t]{2}{*}{ Z } & $0.111 * * *$ & $0.062 * * *$ & $0.125 * * *$ & 1.000 & & & & \\
\hline & $(0.000)$ & $(0.005)$ & $(0.000)$ & & & & & \\
\hline \multirow[t]{2}{*}{ Liq ratio } & $-0.059 * *$ & -0.003 & $-0.169 * * *$ & $-0.098 * * *$ & 1.000 & & & \\
\hline & $(0.011)$ & $(0.908)$ & $(0.000)$ & $(0.000)$ & & & & \\
\hline \multirow[t]{2}{*}{$\mathrm{D} / \mathrm{E}$} & -0.037 & $0.372 * * *$ & $0.128 * * *$ & $0.054 * *$ & -0.011 & 1.000 & & \\
\hline & $(0.071)$ & $(0.000)$ & $(0.000)$ & $(0.013)$ & $(0.645)$ & & & \\
\hline \multirow[t]{2}{*}{$\ln \mathrm{TA}$} & $0.057 * * *$ & 0.012 & $0.382 * * *$ & $-0.12 * * *$ & $-0.094 * * *$ & 0.009 & 1.000 & \\
\hline & $(0.005)$ & $(0.545)$ & $(0.000)$ & $(0.000)$ & $(0.000)$ & $(0.671)$ & & \\
\hline \multirow[t]{2}{*}{ Inf } & 0.019 & 0.011 & 0.013 & 0.015 & -0.015 & -0.004 & -0.005 & 1.000 \\
\hline & $(0.339)$ & $(0.588)$ & $(0.541)$ & $(0.490)$ & $(0.507)$ & $(0.857)$ & $(0.795)$ & \\
\hline
\end{tabular}

Note: Numbers in parentheses are p-values. Significance at the $1 \%$ and $5 \%$ levels is indicated by $* * *$ and $* *$, respectively.

Next, to test the impact of bankruptcy risk on financial performance of Thai listed companies, the three alternative multiple regression analyses are examined based on models (1), (2), and (3), which are: multiple regression models between bankruptcy risk measured by Altman's Z-score; and three alternative financial performance measurements, i.e. ROA, ROE, and Tobin's Q. The control variables in those models are liquidity, leverage, size of firm, and inflation. The results in Table 3 shows there are positive relationships between Altman's Z-score and the three types 
of financial performances - ROA, ROE, and Tobin's Q - at the 1\% significance level. These suggest that companies with high Z-scores or in other words companies with low bankruptcy risk will perform well financially. This finding is consistent with most of the published evidence (Foo, 2015; Foo and Pathak, 2016; Foo, 2018; Foo and Pathak, 2018). There is a positive relationship between $Z$-score and financial performance. In other words, there is a negative relationship between bankruptcy risk and financial performance.

Table 3. Multiple regression analysis

\begin{tabular}{lllll}
\hline & ROA & ROE & TobinQ & \\
\hline Term & Coef & Coef & Coef & VIF \\
\hline Constant & $-9.500^{* * *}$ & $-38.830^{* * *}$ & $-0.454^{* * *}$ & \\
\hline Z & $(-4.1)$ & $(-6.83)$ & $(-9.61)$ & \\
\hline & $1.747^{* * *}$ & $4.907 * * *$ & $0.037^{* * *}$ & 1.020 \\
\hline Liq ratio & $(5.3)$ & $(6.06)$ & $(5.44)$ & \\
\hline & -0.027 & 0.001 & $-0.002^{* * *}$ & 1.020 \\
\hline D/E & $(-1.49)$ & $(0.03)$ & $(-5.41)$ & \\
\hline & -0.015 & $-0.367 * * *$ & $0.001 * * *$ & 1.010 \\
\hline In TA & $(-1.66)$ & $(-16.52)$ & $(6.2)$ & \\
\hline & $0.761 * * *$ & $2.662 * * *$ & $0.054 * * *$ & 1.020 \\
\hline inf & $(5.29)$ & $(7.54)$ & $(18.39)$ & \\
\hline & 0.183 & -0.199 & 0.004 & 1.000 \\
\hline R-sq & $(0.76)$ & $(-0.34)$ & $(0.75)$ & \\
\hline R-sq(adj) & $3.25 \%$ & $16.52 \%$ & $20.07 \%$ & \\
\hline Durbin-Watson Statistic & $2.99 \%$ & $16.29 \%$ & $19.85 \%$ & \\
\hline F-Value & 2.04 & 2.03 & 1.99 & \\
\hline P-Value & 12.13 & 71.27 & 90.54 & \\
\hline Nubs & $0.00 * * *$ & $0.00 * * *$ & $0.00 * * *$ & \\
\hline
\end{tabular}

Note: Numbers in parentheses are p-values. Significance at the $1 \%$ and $5 \%$ levels is indicated by $* * *$ and $* *$, respectively.

Additionally, results in Table 3 show that there is a positive relationship between size of firm and financial performance at the 1\% significance level. Larger companies on the Stock Exchange of Thailand will experience better financial performance than smaller ones. It is possible that larger businesses can create competitive advantage and greater profits based on the economy of scale, and enjoy lower cost of sales per unit than smaller companies. It is also possible that larger companies have easier access to capital and they can profit from lower financial costs than smaller companies.

Table 3 also presents the effects of other variables including liquidity, capital structure and inflation variables on financial performance. Results show that inflation variable insignificantly affects financial performance measured by all three alternative measurements at the 5\% significance level. Interestingly, there are mix effects of liquidity and capital structure variables on financial performance. The findings reveal that the liquidity variable insignificantly affects financial performance measured by ROA and ROE at the 5\% statistical significance level. Nevertheless, it found that the liquidity variable significantly and negatively affects financial performance measured by Tobin's $\mathrm{Q}$ at the $1 \%$ significance level. In other words, companies with higher liquidity will have a lower Tobin's Q. Most investors in the Thai stock market would consider that a firm with a high liquidity ratio would not be very efficient in its short-term asset management, and experience problems like: credit collection inefficiency, resulting in high account receivables; inefficiency in sales and inventory management, resulting in high inventory that is not being sold; and inefficiency in cash management, resulting in high amounts of cash in the company's account. These will 
impact on the company's share price, specifically causing it to fall and resulting in low Tobin's Q which is measured by market data. Furthermore, the findings show that a capital structure variable negatively affects ROE and Tobin's Q but a capital structure variable does not affect the ROA at the $1 \%$ significance level. Hence, these findings do not conclude that liquidity and capital structure variables statistically significantly impact on financial performance in all cases. It depends on the alternative measurement of financial performance that is being utilized.

\section{Conclusion}

Based on a small number of previous studies regarding the impact of bankruptcy risk on financial performance, and according to what the researchers know, no published research has yet looked at the impact of bankruptcy risk on financial performance of companies listed on the Stock Exchange of Thailand. Specifically, not study has to date employed cross-sectional analyses for bankruptcy risk as measured by Altman's Z-score (1968) and alternative measures of financial performance - ROA, ROE, and Tobin's Q. Control variables in the cross-sectional analyses are liquidity, capital structure, size of firm, and inflation. This has now been undertaken in the present study.

This research used the data of companies listed on the Stock Exchange of Thailand between 2015 and 2019, but excluding those businesses operating in the finance industry. The findings reveal that bankruptcy risk measured by Altman's Z-score and firm size positively impact on all three financial performance types, ROA, ROE, and Tobin's Q at the $1 \%$ statistical significance level. It means that large companies listed on the Stock Exchange of Thailand with low bankruptcy risk or high financial stability enjoy a high level of financial performance both in terms of accounting-based performance (ROA and ROE) and market-based performance (Tobin's Q). Added to this, the results show that the statistically significant impacts of liquidity and capital structure on financial performance are mixed depending on financial performance. It is evident that inflation exerts a statistically insignificant impact on all financial performance measures.

The findings of this research suggest that businesses wanting to enhance their financial performance should aim to reduce the conditions that lead to bankruptcy risk and expand their business objectives in order to achieve the economies of scale and lower costs per unit. Investors who want to invest in companies listed on the Stock Exchange of Thailand should focus on large companies with low bankruptcy risk because their financial performance appears to be sound. Results of this study will benefit other stakeholders, such as credit analysts who could consider the bankruptcy risk of firms to estimate their ability to repay loans/debts, when making credit-based decisions. Finally, this research adds much important knowledge on the subject of bankruptcy risk and its impact on companies' financial performance in Thailand. However, this study used data strictly for the period between 2015 and 2019, so future studies should study other developing market economies markets with the same kinds of companies, or indeed choose a longer timeframe for such companies listed on Thailand's stock exchange. Furthermore, other factors could be devised and tested for their impact on financial performance.

\section{References}

Abdul, R., \& Mohamed, N. (2007). Working capital management and profitability-case of Pakistani Firms. International Review of Business Research Papers, 3, 279-300.

Altman, E. I. (1968). Financial ratios, discriminant analysis and the prediction of corporate bankruptcy. The Journal of Finance, 23(4), 589-609. https://doi.org/10.2307/2978933

Altman, E. I., Eom, Y. H., \& Kim, D. W. (1995). Failure prediction: evidence from Korea. Journal of International Financial Management \& Accounting, 6(3), 230-249. https://doi.org/10.1111/j.1467-646X.1995.tb00058.x

Andreas, C., Evi, N., \& Christakis, C. (2004). Predicting corporate failure: empirical evidence for the UK. European Accounting Review, 13, 465-497. https://doi.org/10.1080/0963818042000216811

Anser, R., \& Malik, Q. (2013). Cash conversion cycle and firms' profitability -a study of listed manufacturing companies of Pakistan. IOSR Journal of Business and Management, 8. https://doi.org/10.9790/487X-0828387

Beaver, W. H. (1966). Financial ratios as predictors of failure. Journal of Accounting Research, 4, 71-111. https://doi.org/10.2307/2490171

Bibi, N., \& Amjad, S. (2017). The relationship between liquidity and firms' profitability: a case study of karachi stock exchange. Asian Journal of Finance \& Accounting, 9, 54. https://doi.org/10.5296/ajfa.v9i1.10600

Chen, J. G., Marshall, B. R., Zhang, J., \& Ganesh, S. (2006). Financial distress prediction in China. Review of Pacific Basin Financial Markets and Policies, 9(2), 317-336. https://doi.org/10.1142/s0219091506000744 
Dorothy, O. C., Adanma, S. E., \& Ebue, M. I. (2015). Relationship between inflation and firms' performance-evidence from Nigeria. World Applied Sciences Journal, 33(5), 814-822. Retrieved from http://www.idosi.org/hssj/hssj9(2)14/5.pdf

Eljelly, A. M. A. (2004). Liquidity-profitability tradeoff: An empirical investigation in an emerging market. International Journal of Commerce and Management, 14(2), 48-61. https://doi.org/10.1108/10569210480000179

Foo, S. L. (2015). Financial health \& corporate performance of listed manufacturing companies in Hong Kong \& Singapore: A comparative study of the two asian tigers. Asian Journal of Business and Management, 3(2), 148-154. Retrieved from https://ink.library.smu.edu.sg/soa_research/1594

Foo, S. L., \& Pathak, S. (2016). Financial health and corporate performance of listed manufacturing companies in South Korea and Taiwan: A comparative study of the two asian tigers. Asian Journal of Business and Management, 4(2), 49-55. Retrieved from https://ink.library.smu.edu.sg/soa_research/1521

Galant, A., \& Cadez, S. (2017). Corporate social responsibility and financial performance relationship: A review of measurement approaches. Economic Research-Ekonomska Istraživanja, 30, 676-693. https://doi.org/10.1080/1331677X.2017.1313122

Garcia-Castro, R. A., Miguel, A., \& Canela, M. A. (2010). Does social performance really lead to financial performance? Accounting for endogeneity. Journal of Business Ethics, 92(1), 107-126. https://doi.org/10.1007/s10551-009-0143-8

Hillary, O. K., Nyang'au, A., \& Ngacho, C. (2018). Effects of financial distress on financial performance of manufacturing firms listed in Nairobi securities exchange. International Journals of Academics \& Research, 1(1), 211-220. Retrieved from https://www.ijarke.com/ibmj-vol-1-issue-1

Ho, C., \& Mohd-Raff, N. (2019). External and internal determinants of performances of Shariah and non-Shariah compliant firms. International Journal of Islamic and Middle Eastern Finance and Management, 12, 236-253. https://doi.org/10.1108/IMEFM-08-2017-0202

Joo-Ha, N., \& Taehong, J. (2000). Bankruptcy prediction: evidence from korean listed companies during the IMF crisis. Journal of International Financial Management \& Accounting, 11(3), 178-197. https://doi.org/10.1111/1467-646X.00061

Liang, F. S., \& Pathak, S. (2018a). Financial health \& corporate performance: a comparison of manufacturing companies in China. Journal of Asian Development, 4(2), 123-132. https://doi.org/10.5296/jad.v4i2.13839

Liang, F. S., \& Pathak, S. (2018b). Studying the relationship between performance and z-scores for manufacturing firms in Singapore. Archives of Business Research, 6(11). https://doi.org/10.14738/abr.611.5566

Mahmood, Y., Rizwan, M., \& Rashid, A. (2018). Exploring the relationship between financial distress, financial flexibility, and firm performance: empirical evidence from pakistan stock exchange. Retrieved from https://www.nicerjss.com/index.php/JFME/article/view/68

Maimunah, A., \& Patmawati, I. (2018). Inflation and companies' performance: A cross-sectional analysis. Advanced Science Letters, 24(6), 4750-4755. https://doi.org/10.1166/asl.2018.11694

Mardaconsita, \& Soelton, M. (2019). Analysis of accuracy level of altman z-score model and springate model in measuring the potential of financial distress in plantations industries. International Journal of Economics and Financial Research, 5(2), 16-25. Retrieved from https://ideas.repec.org/a/arp/ijefrr/2019p16-25.html

McGuire, J. B., Sundgren, A., \& Schneeweis, T. (1988). Corporate social responsibility and firm financial performance. The Academy of Management Journal, 31(4), 854-872. https://doi.org/10.5465/256342

Muhammad, S., Rabi'u, S., Jibril Sani, U., Wambai, K., Ibrahim, F. B., \& Jibril, R. S. (2015). The effect of working capital management on corporate profitability: Evidence from Nigerian food product firms. Applied Finance and Accounting, 1(2), 55-63. https://doi.org/10.11114/AFA.V1I2.8

Muhammad, U. (2012). Working capital management and its affect on firm's profitability and liquidity: in other Food Sector of (KSE) Karachi Stock Exchange. Oman Chapter of Arabian Journal of Business and Management Review, 1. https://doi.org/10.12816/0002232

Ohlson, J. A. (1980). Financial ratios and the probabilistic prediction of bankruptcy. Journal of Accounting Research, 18(1), 109-131. https://doi.org/10.2307/2490395 
Pratheepkanth, P. (2011). Capital structure and financial performance: evidence from business companies in colombo stock exchange, Sri-lanka. Researchers World Journal of Arts Science and Commerce, 2(2), 171-180. Retrieved from https://www.semanticscholar.org/paper/CAPITAL-STRUCTURE-AND-FINANCIAL-PERFORMANCE\%3AFROM-Pratheepkanth/f9a6ce485212b0e1d211a11b23663e4559f9bc44

Ramli, N. A., Latan, H., \& Solovida, G. T. (2019). Determinants of capital structure and firm financial performance-A PLS-SEM approach: Evidence from Malaysia and Indonesia. The Quarterly Review of Economics and Finance, 71, 148-160. https://doi.org/10.1016/j.qref.2018.07.001

Rodgers, W., Choy, H. L., \& Guiral, A. (2013). Do investors value a firm's commitment to social activities?. Journal of Business Ethics, 114(4), 607-623. https://doi.org/10.1007/s10551-013-1707-1

Rouf, M. (2015). Capital structure and firm performance of listed non-financial companies in Bangladesh. The International Journal of Applied Economics and Finance, 9, 25-32. https://doi.org/10.3923/ijaef.2015.25.32

Rub, N. A. (2012). Capital structure and firm performance: Evidence from Palestine stock exchange. Journal of Money, Investment and Banking, 23, 109-116. Retrieved from https://www.aaup.edu/publication/noor.aburob/article/capital-structure-and-firm-performance-evidence-palestin e-stock-exchange

Tidathip, P. (2017). Bankruptcy risk analysis using financial ratios for companies of property development sector in the stock exchange of Thailand. Silpakorn University Journal of Social Sciences, Humanities, and Arts, 17(1), 149-159. https://doi.org/10.14456/sujsha.2017.4

Zmijewski, M. E. (1984). Methodological issues related to the estimation of financial distress prediction models. Journal of Accounting Research, 22, 59-82. https://doi.org/10.2307/2490859

\section{Copyrights}

Copyright for this article is retained by the author(s), with first publication rights granted to the journal.

This is an open-access article distributed under the terms and conditions of the Creative Commons Attribution license (http://creativecommons.org/licenses/by/4.0/). 